\title{
Information literacy is not a one-man show
}

\author{
Best Practice Article
}

Mette Bønløkke*, Else Kobow, Anne-Kirstine Kristensen

VIA University College

\begin{abstract}
This article will discuss the issues at stake when cooperation between library and faculty on information literacy (IL) is initiated and explored by using an action research approach. Research on and experiences from cooperation between faculty libraries and faculties indicate that several teaching programmes have not integrated IL into the curriculum nor have they established a formalised cooperation between library and faculty on IL. Participants in the project were three librarians, six lecturers, one library manager, two directors of programme and two project managers from VIA University College, Denmark. The data for this study originates from focus group interviews, process protocols, records of reflective sessions and support meetings as well as from mail correspondences. Results indicate that formal cooperation between librarians and educators is necessary and provides the needed access to the other's understanding of IL, the curriculum, pedagogical professionalism and mutual roles. A joint conceptual understanding of IL is important for making this teamwork work. Librarians need access to programme documents and knowledge on students' level of learning and on course work. Co-teaching supports the librarian in developing pedagogical skills. Educators have diverging experiences with IL which can be a problem when challenging students on IL for their assignments. IL is everyone's business and local dissemination of an agreed curriculum intervention throughout a programme is important. Leadership and re-sources are also significant if the integration of IL is to be possible.
\end{abstract}

\section{Keywords:}

Information literacy, IL, cooperation, faculty, library

\section{*Contact:}

Mette Bønløkke

VIA University College, Silkeborg, Denmark

e-mail:mebo@via.dk

Nordic Journal of Information Literacy in Higher Education, 2015. (C2015 Mette Bønløkke, Else Kobow \& Anne-Kirstine Kristensen.

(cc) BY-NC This is an Open Access article distributed under the terms of the Creative Commons Attribution Noncommercial 3.0 Unported License (http://creativecommons.org/licenses/by-nc/3.0/) 


\section{Introduction}

This article focuses on the issues of importance when cooperation between library and faculty on Information literary (IL) is initiated and explored.

The second cycle of "The framework of qualifications for the European Higher Education Area" states that students on the bachelor level must have "Demonstrated knowledge and understanding that is founded upon, and extends and/or enhances that typically associated with the first cycle, and that provides a basis or opportunity for originality in developing and/or applying ideas, often within a research context" (Videnskabsministeriet, 2005, p.4)

In order to write a bachelor dissertation using an academic method the student must be information literate (IL) (Rienecker \& Stray Jørgensen, 2012). To attain accreditation Danish bachelor programmes in nursing require that scientific methodology; the theories on science and methods for experimental and development work, must be a part of the programme (Danmarks Evalueringsinstitut, 2012). This includes IL. This demand is not clearly specified in all Danish bachelor programmes. A definition of IL in four steps is adopted for this project; "To be information literate, a person must be able to recognize when information is needed and have the ability to locate, evaluate, and use effectively the needed information" (ACRL, 2014).

It is important to integrate IL into the general curriculum (Barnard, Nash, \& O'Brien, 2005; Ford, Foxlee, \& Green, 2009; P. D. Morgan, Fogel, Hicks, Wright, \& Tyler, 2007; Secker, 2011). Time for learning IL must be included in the teaching programme in order to facilitate a learning process that fits the students' need to develop IL. When IL is integrated into the curriculum students will have a higher motivation for becoming information literate and more likely to keep up their acquired skills (Bruce, 2004; Grützmeier M, 2005; Leth Andersen, 2009a; Secker, 2011; Whitehurst, 2010). Achieving academic recognition from educators is a motivational factor for using new knowledge in assignments. When linked to assignments, IL makes sense for students. (Andreasen, Jørgensen, \& Nielsen, 2007; Appleton, 2005; Bønløkke, Kobow, \& Kristensen, 2012b; Klem \& Weiss, 2005). Cooperation between the library and faculty is important in the process of integrating IL into the curriculum (Bønløkke et al., 2012b; DixonThomas, 2012; Moselen \& Wang, 2014).

When searching for information, the students seek meaning as well as sources when searching for information (Kuhlthau, 2004). Therefore librarians must be able to use didactic knowledge and pedagogic skills when teaching IL. They must also be able to understand issues of importance to the students' learning process, the students' prerequisites and their learning outcomes (Appleton, 2005; Gibson \& Luxtin, 2009; Kobow, Bønløkke, \& Kristensen, 2011; Leth Andersen, 2009b; McCluskey, 2010). Studies looking at the role of the librarian in teaching IL show that awareness of the part you play is important (Kuhlthau, 2004). In our previous studies we have found that the main role of the educators is to support students in all four steps of IL. It is also important that the educators show an interest in the student's progression; ask questions about the search the students have carried out, the information located, the selection process and how the information is used. This will make the students aware of the importance of IL especially when linked to the methodology of an assignment (Bønløkke, Kobow, \& Kristensen, 2012a; Bønløkke et al., 2012b; Kobow et al., 2011).

Helping students to develop IL requires the cooperation of librarians and educators. How this cooperation is practiced differ significantly from teaching programme to teaching programme and from library to library. Some librarians have a very close cooperation with lecturers co-teaching IL; some have a contact person in the programme but no real cooperation on the needs of students and the teaching required, but according to Bruce, IL is not a one-man show;

Information literacy education is not possible without partnerships. Students, information specialists, IT specialists, curriculum designers, community organizations, teachers, amongst others, all need an awareness of the value of information literacy, and 
all need to collaborate to make possible learning experiences that facilitate information literacy. We should also note that no single group, in a broad context, nor individuals in a local context, neither governments, nor schools, nor universities, nor teachers, can carry responsibility for information literacy amongst students. This responsibility must be shared within strategic partnerships operating at various levels, including curriculum design, policy development, staff development, research and classroom teaching; and be supported by educational leaders such as principals and deans (Bruce, 2004, p. 13).

Using an action research approach the aims of this study were to:

1. Establish joint student support between librarian and educator

2. Highlight the respective roles of the librarian and the educator in the learning process of the students

3. Ensure that curriculum integration makes sense for the individual teaching programme

This article will describe the outcome of this study with a focus on participant experiences and perceptions. What is of importance in the cooperation between librarians and educators?

\section{Method}

Action research was the chosen method allowing us to implement new knowledge in the organisation at the same time as it was produced. In action research the participants' involvement from start to finish is essential, as they act as co-researchers. Action research is reflective, flexible and processual (Duus, Husted, Kildedal, Laursen, \& Tofteng, 2012; Malterud, 2013; McNiff, 2013). Our process was based on dialogue between all parties involved as a mean to enhance knowledge in the organisations. It was a structured process inspired by Pålshaugen and Hummelvoll and included four stages; preparation, orientation, intervention and evaluation (Hummelvoll \& Severinsson, 2005; Hummelvoll, 2006; Pålshaugen, 1991) lasting from January to December 2013 (Figure 1).

Timetable and activities

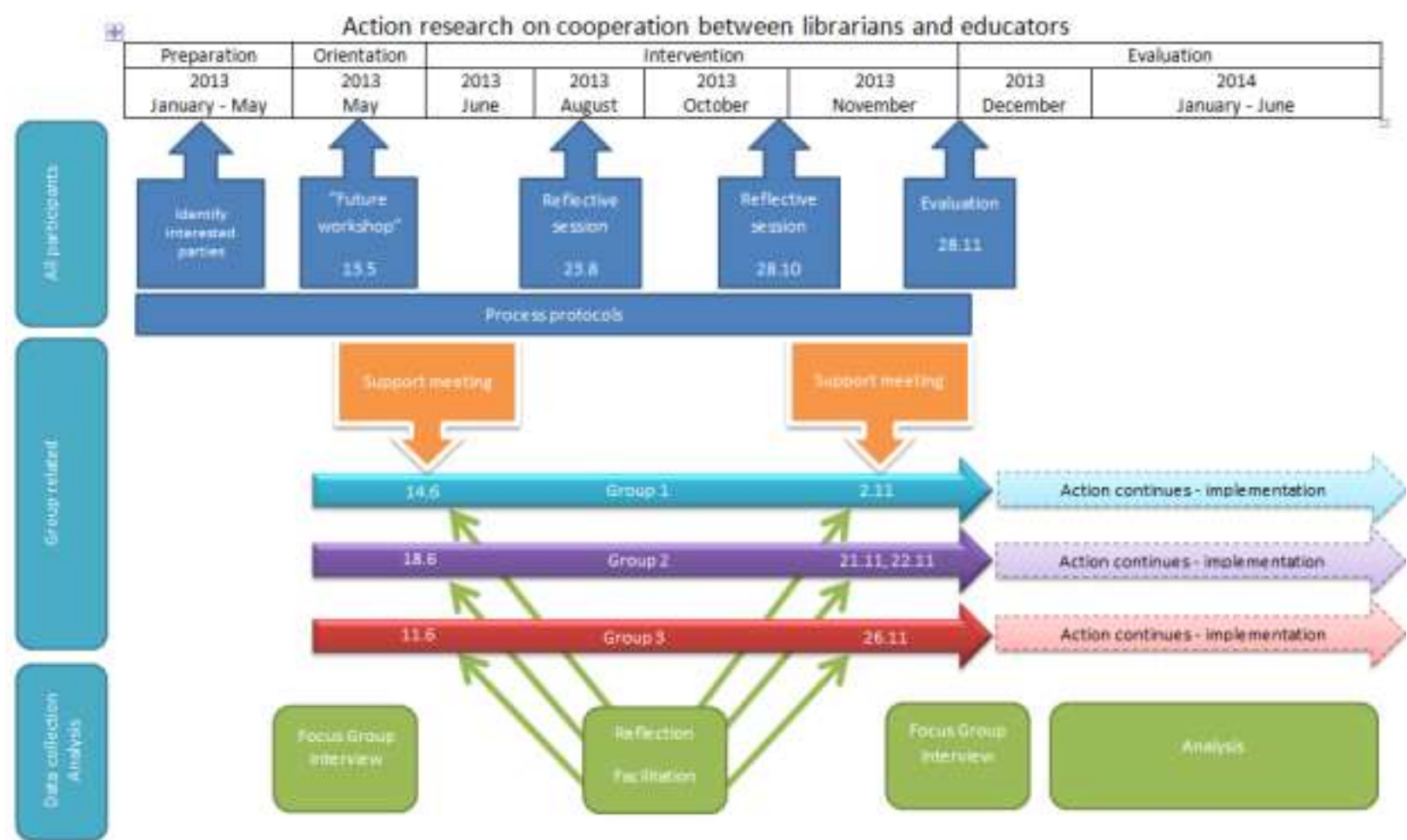

Figure 1. Timetable and activities 
In stage one - preparation - we identified the participants. The participants were: three librarians, one director of library, six educators, and to programme directors (both directors of two programmes). Directors of libraries and programme directors of Nursing, Mechanical engineering and Global Business in Campus Horsens and Silkeborg, Via UC identified the participants interested in taking part in the project. Based on research and literature on IL we agreed that the overall focus should be curriculum integration of IL (Secker, 2011). The aims of the project were defined (see above) and the project did not need ethical approval from The National Committee on Health Research Ethics.

Stage two - orientation - started with a "Future Workshop" for all participants and directors. All gave informed consent to participate in the project (Kvale \& Brinkmann, 2009). A "Future workshop" is a democratic workshop in which everyone is heard and acknowledged (Jungk \& Müllert, 1989). Due to its creative nature the "Future workshop" acted as a kick-starter for the research process and, through dialogue, enabled participants to formulate their primary needs in relation to the integration of IL into the curriculum. The participants decided to work in three groups, each with different local action. Group 1 focused on disseminating curriculum integrated IL within the organisation. This group had previously described curriculum integration of IL and worked according to it, but spreading it throughout the organisation had been unsuccessful. Group 2 focused on the ways in which IL can be continuously designed in the curriculum. This group was in the process of designing a new programme and wanted to integrate IL while implementing the curriculum. For Group 3 the focus was the establishment of cooperation on IL between library and faculty. This group had very little previous cooperation between library and faculty and wanted to start up cooperation on curriculum integration of IL. The participants were encouraged to write process protocols in order to follow the action process and the reflection on it. The first focus group interview was held immediately after the "Future Workshop". This was done in order to define the base line information on the participants' perception on curriculum integration of IL, on cooperation between faculty and library, and on the part IL played in their programmes as well as receiving feedback on the "Future Workshop". Focus group interviews are carefully planned discussions designed substantial data in a short period of time. This method is useful to examine what people think and why. The group interaction present at these interviews can produce a wide range of data as group members interact and inspire each other, thus producing a synergy effect (D. L. Morgan, 1997). The interviews were undertaken by the project managers; the Moderator used interview guides and an observer took notes. In addition, the focus group interviews were audio recorded.

During stage three - intervention - we organised two support meetings with each group and two reflective sessions with all participants. Through dialogue participants shared experiences, gave and got inspiration and exchanged ideas (Duus et al., 2012; Hummelvoll \& Severinsson, 2005; Hummelvoll, 2006). The two project managers supported the action processes, facilitated meetings and sessions and wrote their own process protocol to maintain own reflection (Hummelvolll \& Severinsson, 2005). The meetings were recorded and notes were taken.

In the fourth and final stage - evaluation - a second focus group interview was held in order to evaluate the process. All recorded data was transcribed by the authors. All recordings will be deleted after project publication. In addition to the transcribed data from the two focus group interviews, two reflective sessions and six support meetings, total data collection also included the process protocols and mail correspondence from participants to researches. The participants chose to write a joint process protocol for the group which gave us three protocols. The project managers' protocols were used as a tool to follow the actions and the leaps in the process and not as data in the analysis (Hummelvoll \& Severinsson, 2005). Data was analysed using a phenomenological hermeneutic approach: First a naïve reading, then a structural analysis in three steps; 1 . "what is said", 2. "what is the text about", 3. the text was structured into main categories and sub- categories (Kvale \& Brinkmann, 2009; Henricson, 2014). To give a 
first impression of what data contented we scrutinised all data separately. Data was analysed by the authors independently and coded into meaningful categories and sub-categories. This coding was discussed and agreed between the authors to ensure a valid interpretation. In cases of disagreement, we discussed the audio recordings, the transcribed data and the notes from interviews and meetings to ensure a correct interpretation. The coded data was the recontextualised into a new text, making sure that the meaning from our data remained intact. This text is presented in the results. From the analysis, two categories emerged: "Participants" and "Product" together with several sub-categories (Figure 2). All parts of the project were supervised and followed by a university librarian from Aarhus University and a $\mathrm{PhD}$ in supervision and action research.

\section{Results}

The re-contextualization of the coded data is presented with a few citations from the data in order to document our interpretation.

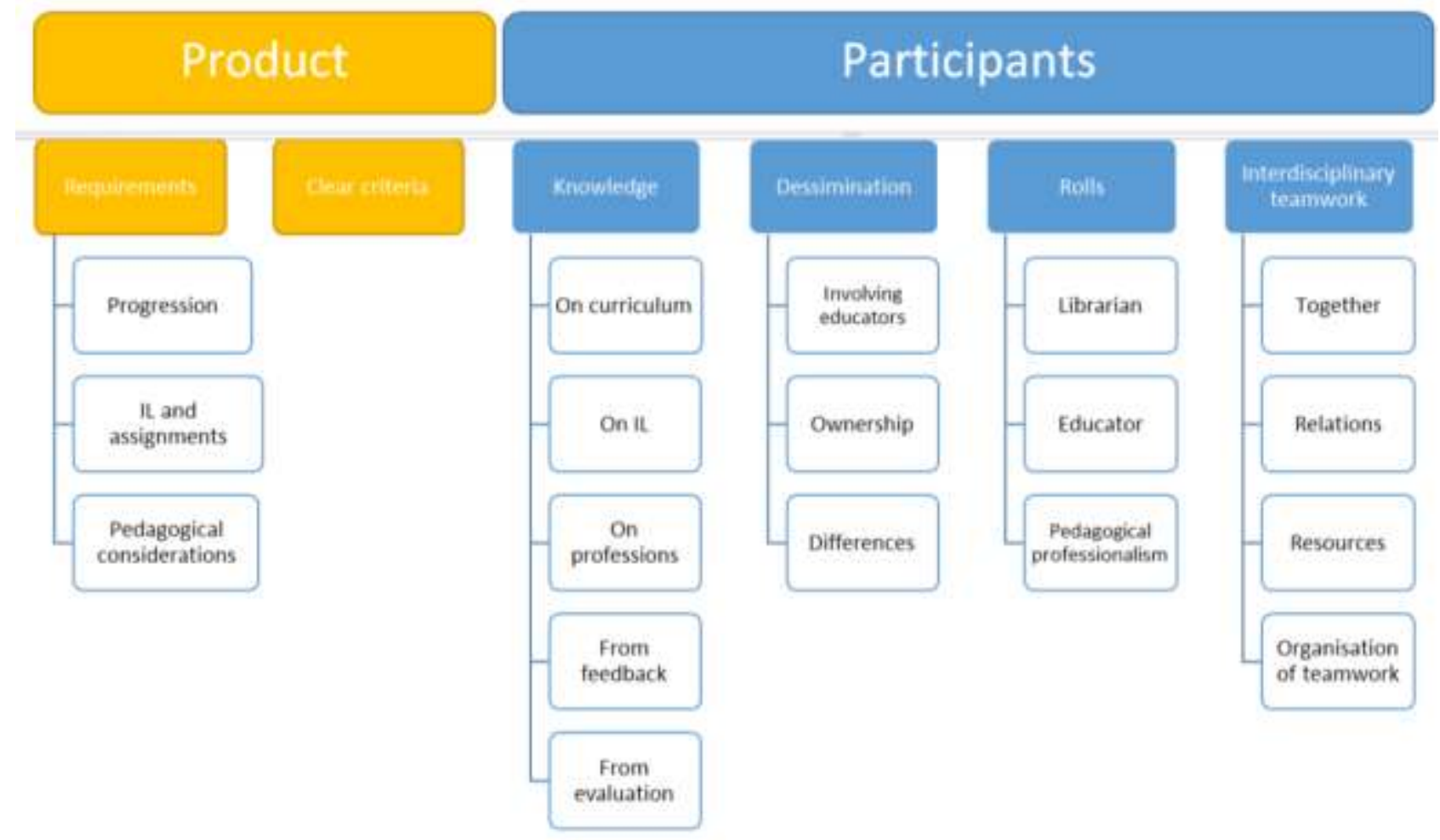

Figure 2. Overview of categories

The category "Participants" describes what seems important for the cooperation, to librarians as well as educator. The category "Product" describes the focus of cooperation; what do the librarian and educator work on together.

\section{Results on Participants}

This category has four sub-categories with various sub-sub categories

\section{Knowledge}

\section{Knowledge on the curriculum}

Librarians do not have knowledge of the level the students have reached, nor of their prerequisites. They do not have access to students' documents and curriculum and are not part of a forum discussing students' learning. Giving the librarian access to knowledge of the curriculum 
makes it easier for them to use their professional capacities and combine the aims for IL with the students' general foci of learning; and thus make it relevant for the students; "Today we have no access to anything on the different programmes" (L1).

\section{Knowledge of IL}

IL seems to be a difficult concept, especially for the educators. The participants find that a number of discussions are called for; discussions on the concept of IL itself, and the role it plays in research methodology. When the educators do not clearly grasp the concept of IL they do not challenge the students in this field when supervising written assignments and do not act as role models for the students.

\section{Knowledge of professions}

Traditionally, librarians have delivered teaching in IL when asked by the educators, and at times when there is a gap in the students' schedule; often without a clear context. When the librarians and educators work together in both the preparation and teaching of IL they become aware of each other's professional knowledge. Understanding and respect of each other's professions seems to enhance the quality of IL learning; "The more I know about the programme, the better and relevant my teaching becomes and I don't feel like an appendix" (L2)

\section{Knowledge from feedback}

On the basis of our study, it appears that students, librarians and educators prosper from feedback on assignments. Students become aware of their competences and levels of learning which can act as a motivational factor for their learning processes. When teaching, the librarians gain insight into the way in which students use information and are thus able to evaluate their teaching. The educators identify the students' level of IL for further support. When joint feedback is delivered with attention to general mistakes, the librarian focuses on technical matters and the lecturer on the use of IL in the assignment.

\section{Knowledge from evaluation}

Evaluation of the joint teaching provides information on the students' experiences. This knowledge is a basis for potential change. The informants of the study express a lack of clear aims for evaluation and how to measure the development of IL.

\section{Dissemination within the organisation}

\section{Involving educators}

For a successful implementation of curriculum integrated IL in an organisation this study points to the importance of involving educators and librarians from the very beginning and throughout the implementation process; "Talking about implementation; it is important that teachers and librarians cooperate from the beginning. If not, misunderstandings can occur" (L3). When educators and librarians have discussions on IL in the context of the curriculum they inspire each other and the chances of dissemination are improved. Our study shows that when the informants mention involvement they talk about a room for discussions, educating each other, and contributing within the group in order to produce clearly defined goals.

\section{Ownership}

Involvement is the key to ownership. To be involved, listened to in a professional discussion, to have responsibility, and take part in developing module description is time-consuming but worth-while; the feeling of ownership is pronounced and implementation is possible. The informants stress that when educating students you also undertake the responsibility of helping students to become information literate; you can't say no.

\section{Differences}

To cooperate with professionals of a different prerequisite knowledge and background appears to open up room for reflection and to further develop your individual professionalisms. The 
differences contained in this project are verbalized as differences in culture, programme and professional background. These differences can let down the students when criteria for assignments are unclear or difficult to interpret, therefore discussions of these issues are important, though time-consuming.

\section{Roles}

\section{The librarian's role}

Generally cooperation between library and faculty exists but it differs from library to library and from programme to programme. In addition, our study shows that the roles of the librarian and educator respectively are very clear to some but not to others.

The librarians seem to need the experience of the educators when teaching jointly in the classroom and in the supervision of the students; “I don't supervise the students then; I don't have the same expertise as you (educators) have. I don't have the professional knowledge even though I have been here for many years now" (L3).

When the librarian teaches IL detached from the students' assignment or general learning aims, it becomes a "one-man show". When the librarians are involved in the assignments there is a clearer focus on IL and handling references. Librarians understand their role as supervisors and teachers of a class or group of students and a responsibility for being available at the library. They also discuss their role as challenging when students critically select materials for assignments.

\section{The educators' role}

The educators experience their role differently according to how involved they have been in the students' development of IL. Some do not focus on IL but see it as a job for the librarian. Others challenge the students' use of results from the search process using their professional background. Some educators seem unaware of critical appraisal and relevant databases; "There is a huge variation in the educators' competences; some are experienced other are less experienced" (E1). Educators, who have taught IL in cooperation with librarians, experience their role as complementing the librarians' knowledge with their own expertise. All agree that more involvement in IL is necessary.

\section{Pedagogical professionalism}

Pedagogical professionalism is defined by the librarians as the ability to reflect and make changes continuously, possibly in cooperation with an educator. It is important to meet the students' needs; they have different levels of IL, some are "Google users", others can find information systematically in relevant databases.

As part of their teaching, the librarians generally try to make sure that everyone is at a certain level. Whereas educators, knowing the students' prerequisites, keep in mind the focus and aim for the lecture and disregard that some students need continuous repetition. The librarians find it difficult to contain the students' frustrations; the educators are better suited at dealing with those. If students need further help they can book an appointment with a librarian.

\section{Interdisciplinary teamwork}

\section{Together}

The informants express the importance of a common goal and room for reflection when developing curriculum integrated IL and teaching. They complement each other and find their different roles based on each other's professional background; the more communication the better the outcome. A teaching session with common aims makes it possible to send clear and identical messages to the students. 


\section{Relations}

As in life, good relationships take time to develop. When they do develop between librarian and educator it becomes possible to create a fertile teamwork based on respect, understanding, learning from each other and developing consensus in joint actions; "We have had a really good team-work, a fertile cooperation too, and we have discovered that the more we communicate the better our product becomes" (L2). Personal relations make it easier to meet informally to clarify questions. The informants state that a good relationship between librarian and educator enhances the students' awareness on IL.

\section{Resources}

The informants stress the importance of available resources for all parties in order to develop the IL of students; these include resources for development, planning, performing and continuous feedback and evaluation. The resources must be visible to avoid the feeling of being exploited, frustration, and stressed employees.

\section{Organisation of teamwork}

It seems important to develop a formal cooperation instead of an informal one; a formal forum with common aims, named members and contacts to educators working in different areas of the college. A close connection between library and faculty is desirable in order to allow the pooling of knowledge on IL.

\section{Results on Product}

\section{Clear Criteria}

If IL is incorporated in curriculum documents it is often unclear what is actually meant by it; which competences are expected and what is required in assignments. When these issues are left vague, IL is open for interpretation by all parties. Our study has shown that there is a need for clearly defined criteria and programme descriptions to prevent confused students and educators. The expectations and level for the assignment must be clear. It seems to strengthen the clarification of what is required if the librarian contributes to the writing of the criteria and if the expectations are described in detail according to the students' level of learning.

\section{Requirements}

\section{Progression}

According to our study, it is important for the informants that IL builds on previous learning one step at a time - and is linked to other learning outcomes within the programme. Progression must be explicit within the teaching programme, in modules or semesters and the complicity of information searches must be seen to increase throughout the programme. It must be clear where in the programme the students work on which step in their acquisition of IL.

\section{IL and assignments}

IL and the academic skill of writing an assignment are linked, but how is not obvious to students, as well as to some educators and librarians. An information search is documented within the academic assignment; often when the method of research is described. Clarification is called for in order to identify what is universal for a student's academic level and what is important and relevant for a certain programme and specific learning outcome. As an informant states, referring to information search; "Having an empty methodology description is not OK" (D1). Results of our study indicate that references to literature on IL help students and their supervisors to clarify expectations for an assignment. 


\section{Pedagogical consideration}

Informants state that IL is neither easily taught nor learned. It does not make sense to some students even though they see themselves as capable information searchers and users - they know Google. It is very important to recognise the competences the students already have but also to make it plain to them what competences they lack in the context of an academic education. The informants recognise the significance of identifying the students' level of knowledge and building on these prerequisites in the teaching and support that they offer.

\section{Discussion}

In action research you depend completely on your participants as they act as co-researchers. You are not in control and cannot predict the process. You can only make an overall framework of a project, facilitate the process, and then wait and see (Duus et al., 2012; Hummelvoll \& Severinsson, 2005; McNiff, 2013). We were lucky that our co-researches were well chosen by the directors. Had this not been the case, the process might not have produced new knowledge for the organisations. All participants were highly engaged and professional. They challenged each other respectfully and supported each other's process although, at first, they struggled with the diversity of the three groups. From the beginning we stressed that all actions should arise from local needs, but there was an expectation of having to reach the same endpoint. Through dialogue the participants realised that this was not the point and were satisfied with their individual processes and able to use their differences constructively.

The entire process was fortunately well supported by the directors. They were involved and interested which meant that the new knowledge created by the project was spread throughout the organisation, and there was an enduring awareness that new knowledge in one area can call for changes elsewhere in the organisation. Leadership in changing processes is essential (Kotter, 1996). The participants and directors took responsibility and ownership. As one librarian said "It is our process, and you are welcome to look (L1)".

Not being in control of the actions performed, the focus of the project mainly enables us to say something about the first two aims. A joint support was establishes through formalised co-operation and the roles of librarians and educators were illuminated. All agreed on curriculum integration as an important issue and worked from that, but the length of the project made it impossible for all groups to get as far as ensuring that curriculum integration made sense for individual programmes. The work continues in the three groups.

We had intended the protocols of the participants would provide valuable information on the process. This was not the case. The protocols turned out to be a status of steps in the process with only little reflection. Writing protocols was not a priority for the participants. Instead, experiences on the process were verbalised at all meetings and became data though the recordings. During meetings and focus group interviews everybody was very positive and showed active engagement in the process. There were no critical voices despite the fact that they were encouraged in the interviews. This might be due to the difficulty of going against the atmosphere of a group, but it has not been possible to ascertain. We had two external critical voices following the process and reflecting with us as researchers which helped us to keep a professional distance to the action processes (McNiff, 2013).

The collected data was plentiful and originated from a variety sources, giving us access to participants' thoughts in and about the process as well as their personal theories on their professional practice. Using data from different sources ensured validity. Using qualitative analysis made it possible to stay close to the experiences of the participants. Being more than one analyser provided fruitful discussions and made us very aware of the interpretation process and the importance of keeping close to data. This also helped us to reach a trustworthy interpretation (Kvale \& Brinkmann, 2009). 
Several issues have been identified as relevant for discussion but we will focus on pedagogical professionalism in librarian and educator and their cooperation.

A transition from service provider to teacher seems to be important for librarians now and in the future, and is a challenge to the librarians' professional identity (Moselen \& Wang, 2014; Torras \& Sætre, 2009; Whitworth, 2012). Moselen and Wang (2014) describe some of the barriers which librarians experience, such as lack of confidence, lack of knowledge of the curriculum and an awareness of the educators lack of knowledge on IL. Other studies show that the change of role for the librarian is taken seriously by providing them with teaching courses and focus on this development when describing their future role (Torras \& Sætre, 2009; Whitworth, 2012). Our study confirms the need to develop the librarians' pedagogical skills in or-der to support their professional identity.

As stated in this and other studies (Moselen \& Wang, 2014) access to information on the curriculum and other information on the students' programme help librarians to make IL relevant by linking it to the students' current work. If no or very little cooperation exists between library and faculty this information becomes difficult for librarians to locate. They may not even know its value as it has never been part of their former preparation for delivering teaching on IL.

The role of the educators is also a challenge to be met. Studies describe that lack of joint conceptual understanding of IL makes communication and cooperation difficult and the educators' lack of knowledge on IL is a barrier when supervising students (Overgaard \& Grundsøe, 2014; Perselli \& Åman, 2006). Describing how educators stood on different levels of IL and some were unable to challenge students in their acquisition of IL, our study confirms this. Supervisors are familiar with challenging students in their learning processes and academic achievements. Being aware of the content of the concept of IL could help them to clarify the roles they play in helping students develop the skills of IL. The question is to what degree do educators need to be IL in or-der to supervise students. Few studies have looked at the educators' role in IL and none provide a clear answer to this question. As knowledge gives security in performance (Dale, 1989) being comfortable with the search process might make it easier for educators to challenge students on IL.

Several previous studies focus on the significance of cooperation between library and faculty (Horntvedt, \& Holmen, 2013; Moselen \& Wang, 2014; Nordsteien, Rushton \& Lahlafi, 2013; Whitworth, 2012) and the value of collaboration is confirmed in this study. It appears to be something students, educators and librarians wish for and recommend (Dixon-Thomas, 2012; Overgaard \& Grundsøe, 2014). Similar arguments can be made for feedback on IL. Students learn from feedback and it enhances their learning process (Hattie, 2009). All this is, however, time-consuming and a general concern raised in this study was available resources. Team teaching and close cooperation between library and faculty takes time and in some cases librarians cover sever-al programmes and will be very hard pressed to teach continuously in a programme as suggested by some studies (Rushton \& Lahlafi, 2013; Secker, 2011). A formal relationship with educators as suggested in this study calls for the prioritisation of IL on all levels. Directors of library and faculty must recognise the importance of IL and delegate the resources to make it work, as also stated by Bruce and others (Rushton \& Lahlafi, 2013).

The recommendations of a closer cooperation between library and faculty are based on developments in society, the possibilities given by IT and the challenges this creates for librarians in colleges of higher education. Our study cannot demonstrate an impact on students' IL from close cooperation between library and faculty, but on the other hand, studies show that the involvement of librarians as well as educators in the students' IL is the way forward (Moselen \& Wang, 2014; Secker, 2011) and provides students with a clearer picture of what is 
expected and makes IL understandable and meaningful (Bønløkke et al., 2012a; Bønløkke et al., $2012 \mathrm{~b}$ ). With curriculum integrated IL as the aim, dissemination of IL throughout an organisation is essential but faces a number of barriers from students, educators and librarians (Secker, 2011). Any new initiative in an organisation calls for leadership (Kotter, 1996). A dialogue in which everyone is listened to and heard in a democratic process is a way to overcome barriers such as low motivation when engaging in a new field of one's profession. Through dialogue it becomes apparent what a society needs and the directions in which a profession develops; a sense of urgency for change might appear as a base for ownership to change (Kotter, 1996; McNiff, 2013). In this project the dialogue seemed to work and contributed to produce new knowledge in the organisation concerning cooperation on curriculum integrated IL.

\section{Conclusion}

Formal cooperation between librarians and educators is necessary in the process of integrating IL into the curriculum; the two parties learn from each other and acquire access to each other's knowledge of IL, curriculum, pedagogical professionalism and mutual roles. Joint conceptual understanding of IL is important for the teamwork and in order to have common and clear aims for the IL of the students. Librarians should know the curriculum, have access to programme documents, know the students' prerequisites and evaluations on course work in order to deliver best professional practice. Co-teaching helps the librarians in developing their pedagogical skills and makes the focus and relevance of IL clearer for the students. This study has showed that educators possess a different experience of IL from librarians and that this can be a problem when challenging students on IL for their assignments. As shown by this and other studies, IL is everyone's business and local dissemination throughout a faculty of an agreed curriculum intervention is important. Leadership and resources are also significant factors for integration of IL.

\section{Perspective}

Throughout all educational institutions the huge amount of information available is a challenge, and in many cases so is the students' level of IL. The results from this study might provide inspiration for librarians and educators working with students on development of IL. We have highlighted the elements which seem to be of importance in the cooperation between the librarian and the lecturer and have described the issues that must be addressed and focused on in their cooperation. 


\section{References}

ACRL. (2014). Information literacy competency standards for higher education. Association of college \& research libraries (ACRL). Retrieved from

http://www.ala.org/acrl/standards/informationliteracycompetency\#ilhed

Andreasen, L. B., Jørgensen, L., \& Nielsen, J. L. (2007). Udvikling af informationskompetence i problemorienterede læreprocesser [Developing information literacy in problem based learning processes]. In M. Rosenstand, K. Harbo \& L. B. Andreasen (Eds.), Fra information til læring (pp. 75-90). København: Deff.

Appleton, L. (2005). Examination of the impact of information-skills training on the academic work of health-studies students: A single case study. Health Information and Libraries Journal, 22(3), 164-172.

Barnard, A., Nash, R., \& O'Brien, M. (2005). Information literacy: Developing lifelong skills through nursing education. The Journal of Nursing Education, 44(11), 505-510.

Bønløkke, M., Kobow, E., \& Kristensen, A. (2012a). Konkret informationssøgning giver de bedste resultater [Concrete information search proves to give the best results]. Sygeplejersken, 112(9), 57-60.

Bønløkke, M., Kobow, E., \& Kristensen, A. (2012b). Curriculum integrated information literacy: A challenge.] Vård i Norden, 32(3), 53-55.

Bruce, C. (2004). Information literacy as a catalyst for educational change: A background paper. Australia: Queenlands University of Technology.

Dale, E. (1989). Pedagogisk professionalitet [Pedagogic professionalism]. Oslo: Gyldendal Norsk Forlag.

Danmarks Evalueringsinstitut. (2012). Vejledning til akkreditering af eksisterende udbudssteder for erhvervsakademiuddannelser og professionsbachelor-uddannelser.[Guide to accreditation for excisting vocational education programmes and professional bachelor programmes] ( No. 6. rev. ed.). København: Danmarks Evalueringsinstitut.

Dixon-Thomas, C. (2012). Information literacy and the 21st century academic librarian: A delphi study (Phd thesis). Capella University, Minneapolis . Retrieved from http://gradworks.umi.com/34/95/3495142.html

Duus, G., Husted, M., Kildedal, K., Laursen, E., \& Tofteng, D. (Eds.). (2012). Aktionsforskning : En grundbog [Action research: Textbook]. Frederiksberg: Samfundslitteratur.

Ford, P. J., Foxlee, N., \& Green, W. (2009). Developing information literacy with first year oral health students. European Journal of Dental Education: Official Journal of the Association for Dental Education in Europe, 13(1), 46-51. doi:10.1111/j.1600-0579.2008.00536.x

Gibson, S., \& Luxtin, J. (2009). Departure from the library desk! one undergraduate programme's story of its subject librarian's evolving role. SCONUL Fokus, 45, 41-44.

Grützmeier M. (2005). Informationskompetence: En udfordring til undervisere [Information literacy: A challenge for educators]. DF Revy, 3, 17-19. 
Hattie, J. A. C. (2009). Visible learning : A synthesis of over 800 meta-analyses relating to achievement. London: Routledge.

Henricson, M. (Ed.). (2014). Videnskabelig teori og metode: Fra idé til eksamination [Scientific $t$ heory and methodology: Form idea to examination] (1st ed.). Kbh.: Munksgaard.

Hummelvoll, J.K. \& Severinsson, E. (2005). Researchers' experience of co-operative inquiry in acute mental health care. Journal of Advanced Nursing, 52(2), 180-188.

Hummelvoll, J.K. (2006). Handlingsorienteret forskningssamarbejde [Co-operative inquiry theoretical reasoning and practical implications]. Norsk Tidsskrift for Sygeplejeforskning, 1, 17-30.

Jungk, R., \& Müllert, N. R. (1989). Håndbog i fremtidsværksteder [Handbook in Future Workshops] (2nd ed.). Kbh.: Politisk revy.

Klem, M. L., \& Weiss, P. M. (2005). Evidence-based resources and the role of librarians in developing evidence-based practice curricula. Journal og Professional Nursing, 21(6), 380-387.

Kobow, E., Bønløkke, M., \& Kristensen, A. (2011). En pædagogisk udfordring [A pedagocical challenge]. Revy, 34(6), 16-18.

Kotter, J. P. (1996). Leading change. Boston, Mass.: Harvard Business School.

Kuhlthau, C. C. (2004). Seeking meaning : A process approach to library and information services (2nd ed.). Westport: Libraries.

Kvale, S., \& Brinkmann, S. (2009). Interview: Introduktion til et håndværk [Interview: Introduction to craftmanship] (2. udgave ed.). Kbh.: Hans Reitzel.

Leth Andersen, H. (Ed.) (2009). Informationskompetence i udvikling [Information literacy in development]. Århus: Center for Undervisningsudvikling, Aarhus Universitet.

Malterud, K. (2013). Kvalitative metoder i medisinsk forskning - en innføring [Qualitativ methods in medical research - an introduction] (3rd ed.). Oslo: Universitetsforlaget.

McCluskey, C. (2010). Learning and teaching in action. beyond the library: Reflections from a librarian in an academic faculty. Health Information \& Libraries Journal, 27(3), 249-252.

McNiff, J. (2013). Action research : Principles and practice (3rd ed.). London: Routledge.

Morgan, D. L. (1997). Focus groups as qualitative research (2nd ed.). Thousand Oaks, Calif.: Sage.

Morgan, P. D., Fogel, J., Hicks, P., Wright, L., \& Tyler, I. (2007). Strategic enhancement of nursing students information literacy skills: Interdisciplinary perspectives. Journal of Association of Black Nursing Faculty, 18(2), 40-45.

Moselen, C., \& Wang, L. (2014). Integrating information literacy into academic curricula: A professional development programme for librarians at the University of Auckland. Journal of Academic Librarianship, 40(2), 116-123. 
Nordsteien, A., Horntvedt, M. T., \& Holmen, N. T. (2013). The development of a model for teaching information literacy to nursing students through cross-professional collaboration. Nordic Journal of Information Literacy in Higher Education, 5(1), 32-37.

Overgaard, C., \& Grundsøe, M. B. (2014). Fokus på informationskompetence i et tværfagligt læringsmiljø - et empirisk studie af læringseffekter og studenterperspektiver [Focus and information literacy in an interdisciplinary learning environment - an empirical study on learning outcome and student perspectives]. Dansk Underversitetspædagogisk Tidsskrift, 9(16), 124-143.

Pålshaugen, Ø. (1991). Som sagt, så gjort?: Språket som virkemiddel i organisasjonsutvikling og aksjonsforskning [No sooner said than done?: language as a tool in organisational development and action research]. Oslo: Novus.

Perselli, A., \& Åman, K. G. (2006). Universitetslärares syn på studenters informationskompetens vid Linköpings Universitet. [University teacher's view on students' information literacy at Linköping University. ( No. CUL-Rapport nr 11). Linköping: Centrum för Undervisning och Lärande.

Rienecker, L., \& Stray Jørgensen, P. (2012). Den gode opgave: Håndbog i opgaveskrivning på videregående uddannelser [A good paper: a handbook for writing papers in higher education] (4. udgave ed.). Frederiksberg: Samfundslitteratur.

Rushton, D., \& Lahlafi, A. (2013). The value and impact of cross professional collaborations in developing student information and academic literacy skills at Sheffield Hallam university, UK. Nordic Journal of Information Literacy in Higher Education, 5(1), 38-43.

Secker, J. (2011). A new curriculum for information literacy. Transitional, transferable, transformational. Cambridge: Cambridge University.

Torras, M., \& Sætre, T. P. (2009). Information literacy education - a process approac : Professionalising the pedagogical role of academic libraries. Oxford: Chandos Publishing.

Videnskabsministeriet. (2005). A framework for qualifications of the European higher education area: Bologna working group on qualifications frameworks. København: Videnskabsministeriet.

Whitehurst, A. P. (2010). Information literacy and global readiness: Library involvement can make a world of difference. Behavioral \& Social Sciences Librarian, 29(3), 207-232.

Whitworth, A. (2012). The reflective information literacy educator. Nordic Journal of Information Literacy in Higher Education, 4(1), 38-55. 